\title{
都市を対象とした環境資源勘定の構築に関する研究
}

\section{APPLICATION OF ENVIRONMENTAL RESOURCE ACCOUNTING TO FUKUOKA CITY}

谷川寛樹*、松本亨*、井村秀文* Hiroki TANIKAWA*, Tohru MATSUMOTO*, Hidefumi IMURA*

\begin{abstract}
A framework of environmental resource accounting appropriate for a specific region such as an area of a certain prefecture or a municipality is presented and tested. Firstly, values of environmental resources are discussed in terms of economic benefits or environmental service they provide, and methods to estimate such values are reviewed. Then, the methods are applied to Fukuoka City. The cost to maintain the present quality of air and water in the City are estimated to be 5.5 and 70 billion yen, respectively. Willingness to pay (WTP) for them are 3.0 and 3.4 billion yen, respectively, while that for the natural environment 2.8 billion yen. The value of parks obtained by the Hedonic approach is 36 billion yen.
\end{abstract}

KEYWORDS; Environmental resource accounting, Direct non-market, Indirect non-market, Willingness to pay, Willingness to accept compensation, Hedonic approach

\section{1.はじめに : 都市における環境資源勘定について}

経済発展と地域環境・地球環境保全との関係を論じるためのベースとなる環境資源勘定の必要性が指摘さ れている。その理論及び実践的手法については、現在、世界各国で多様な試みが試行錯誤的に行われていると ころである。これを一般論、抽象論から具体的な議論へと発展させるためには、実行可能な方法を提示し、そ れの実際的適用事例をレビューしあうことが重要である。現在の検討事例としては、国レベルのものが多いが、 それと並行して、多様な地域特性を考慮した地域規模での検討も重要な位置を占める。ここで、環境資源勘定 は、今後の地域環境管理施策の基盤的情報となるものと著者らは考えている。また、地域規模のアプローチの 方が、現地に即した環境要素ごとのデータが入手でき、地域レベルでの環境資源の価值のきめ細かな評価、さ らには資源循環や人間活動と環境質との関係も容易だという利点もある。

著者らは都市に着目した環境資源勘定について、都市のマテリアルフローの側面から評価するために、工 ネルギー及び物質別のフローとストックを定量化してきた。本研究では、まずこの従前研究の延長として、こ れまでの一連の研究によって得られた物的勘定データを整理・体系化する。次に、都市内に賦存する各種環境 資源が有する価値（存在価值）の定量化を試みる。具体的には、「直接的非市場評価」による大気質・水質悪 化の評価、間接的非市場評価」による土地の市場価格を利用した緑地の評価、及び、大気質・水質の污染防 止費用について環境の価値評価を試み、それらの結果を都市の環境資源勘定として統合する方法について考 察する。なお、手法の具体的適用は福岡市を対象として取り上げる。

\section{2. 都市の環境資源勘定の枠組み}

自然資源は、社会に財・サービスを提供し、社会から廃棄物を受け取る。環境資源勘定の体系そのものは まだ確立されたものではないが、1つのプロトタイプとして国や地域における自然資源の量的増減のフロー及 びストックを表す物的勘定 (一種のマテリアルバランス表) がある。さらに、これに貨幣的な価値勘定を結合 させることによって国民経済勘定（SNA）に連動させていこうとする試みもなされている。

*九州大学工学部環境システム工学研究センター *Institute of Environmental Systems, Faculty of Engineering, Kyushu University 
地域の環境管理のためには、まず、質と量の両面か ら環境資源を管理する物的勘定が必要である。次い で、経済発展と環境保全という政策目標を統合するた めに、貨幣価値で表された何らかの勘定が求められる といえる。

図2-1は、都市での環境資源勘定の枠組みを示した ものである。都市の環境資源を物的側面と質的側面に 分け、それぞれで評価を行う。物的勘定では、生産 消費・廃棄・再利用を通じたエネルギーや物質のフ ロー及びストックを推計する。それに伴う便益と環境 負荷の推定もあわせて行う。質的勘定については、都 市の環境資源を大気・水・土・生物に分け、市場評価・ 非市場評価により貨幣的な価值を推計する。表 2-1 は、都市の環境資源の種類と評価方法を示したもので ある。さらに、両体系から得られたデータを総合的に 評価するために統合勘定として、以下の式により都市 の環境資源勘定を求める。

都市の環境資源勘定 $=$ 都市の総所得

一都市の環境資産の減少分

一都市の環境保全対策費用

一地球の環境資産の減少分

一地球の環境保全対策費用

十都市の環境便益の増加分

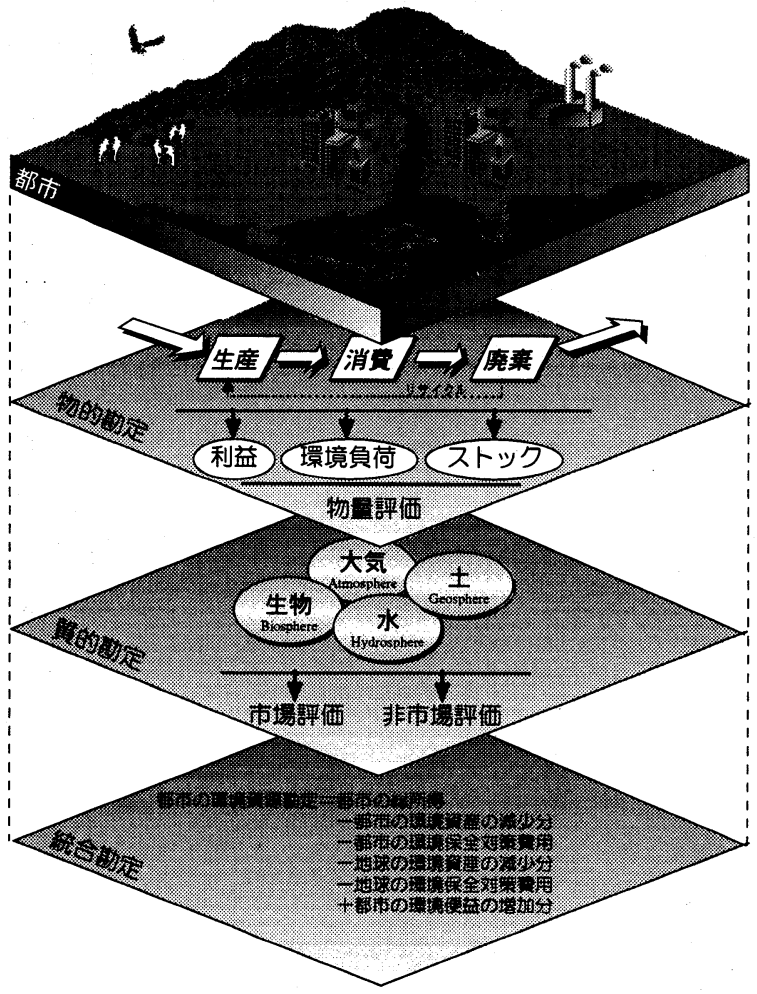

図 2-1＼cjkstart環境資源勘定の枠組み

\section{3. 物的勘定のケーススタディ}

\section{1 都市における物的勘定の推計手法}

物質・エネルギーの循環はきわめて複雑で、全てを正確に把握することは困難である。筆者らはこれまで

\begin{tabular}{|c|c|c|c|}
\hline \multicolumn{4}{|c|}{ 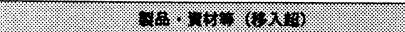 } \\
\hline 建设隻材 & & 科入 & 移出 \\
\hline 木材 & $: \quad 59,000 t($ & $+156,000$ & $-97,000)$ \\
\hline 秒利・醉石 & $: 1,930,000 \mathrm{t}(t$ & $+3,500,000$ & $-1,570,000)$ \\
\hline 跃鼠 & $: 209,000+i$ & $+365,000$ & $-156,000)$ \\
\hline セメント & $: 231,000 \mathrm{t}$ & $+413,000$ & $-182,000)$ \\
\hline その他 & $: 59,000+c$ & $+156,000$ & $-97,000)$ \\
\hline 石战策品 & \multicolumn{3}{|c|}{$: 1,080,000 \mathrm{Gcal}$} \\
\hline 石油製品 & \multirow{2}{*}{\multicolumn{3}{|c|}{$: 13,900,000 \mathrm{Gcal}$}} \\
\hline 践産品 & & & \\
\hline 石灰石 & \multicolumn{3}{|l|}{$: 600,000 t$} \\
\hline 阵颣 & \multicolumn{3}{|l|}{$: \quad 158,000 t$} \\
\hline 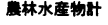 & \multicolumn{3}{|l|}{$: 263,000 t$} \\
\hline
\end{tabular}
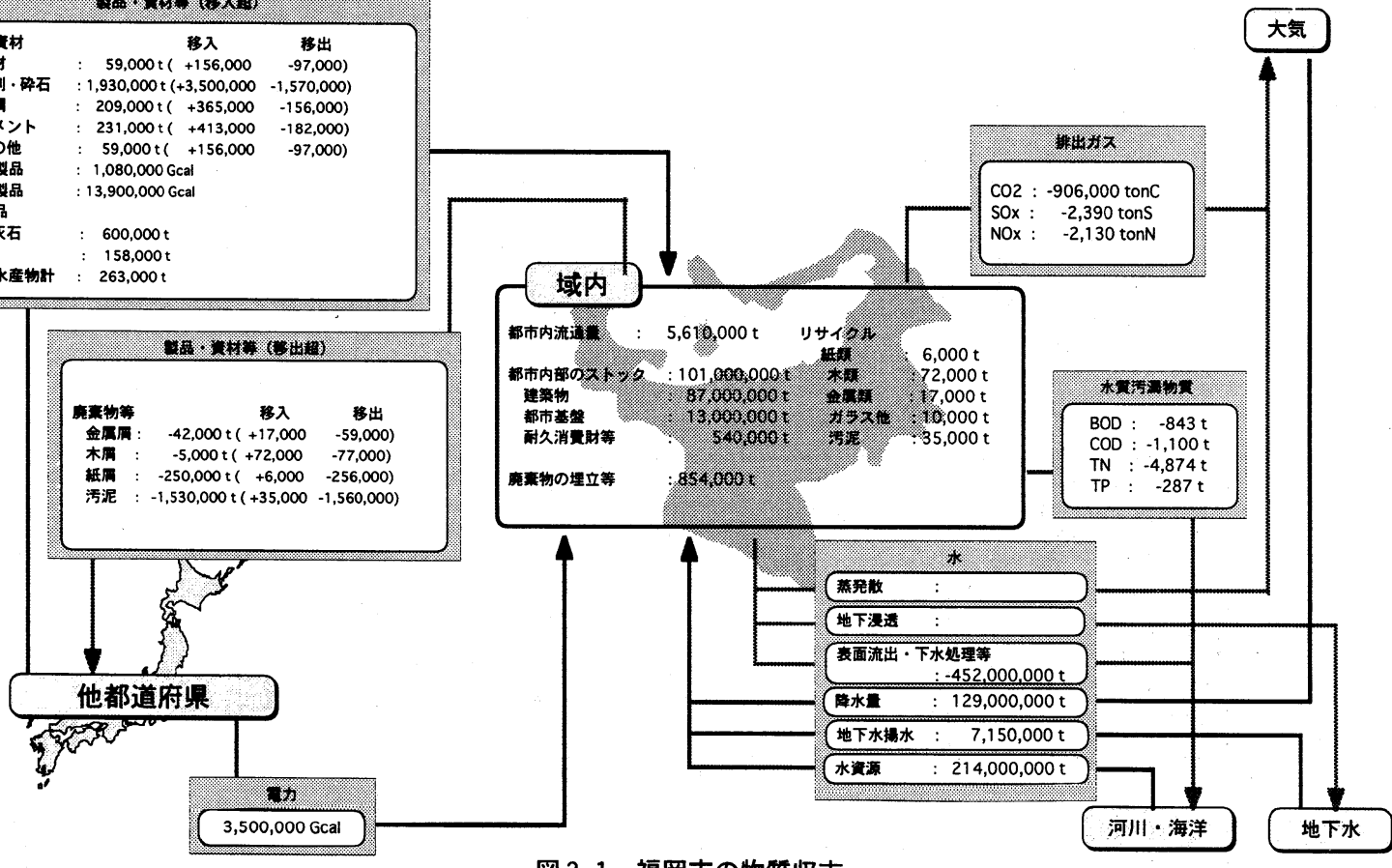

図 3-1 福岡市の物筫収支 


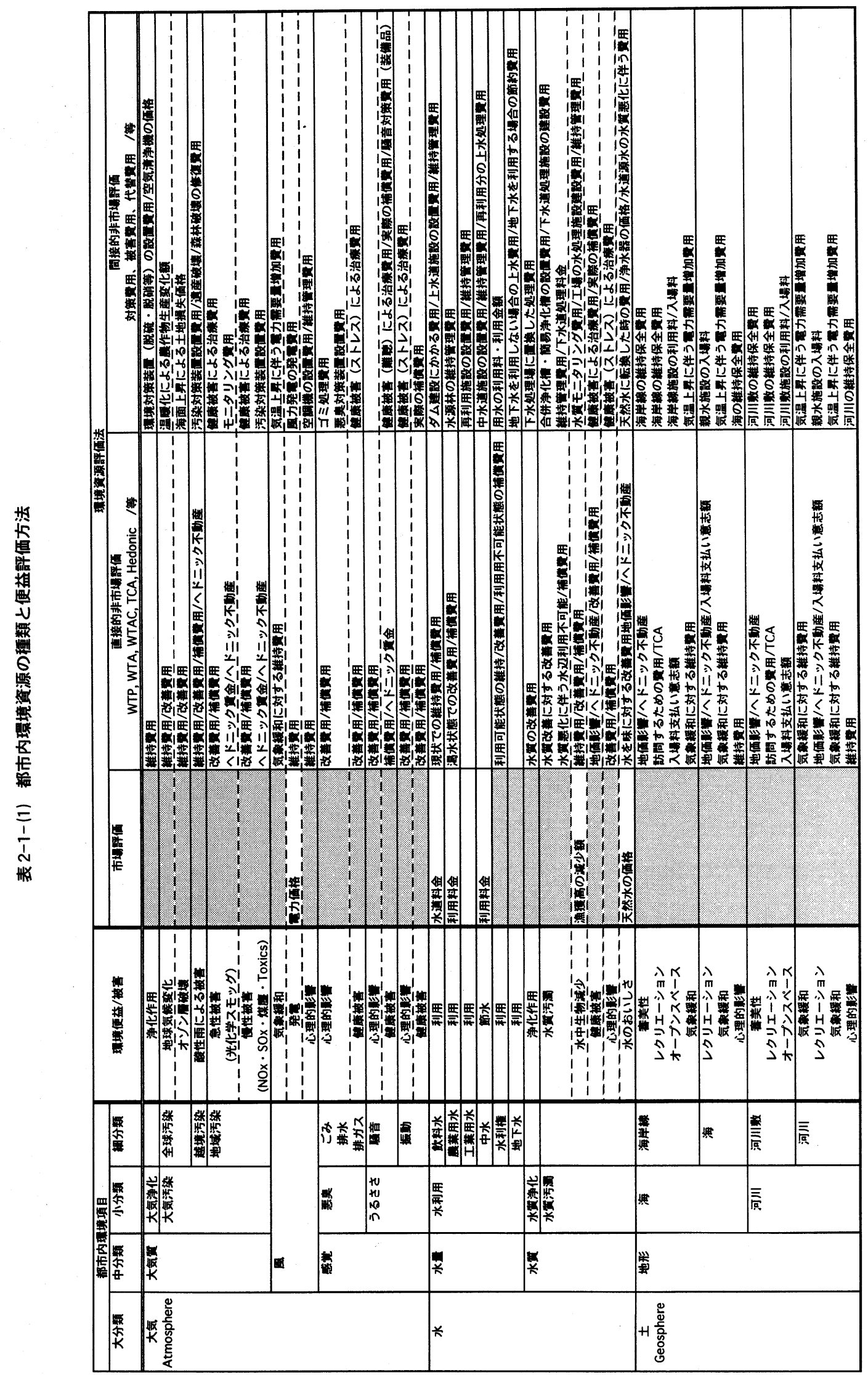




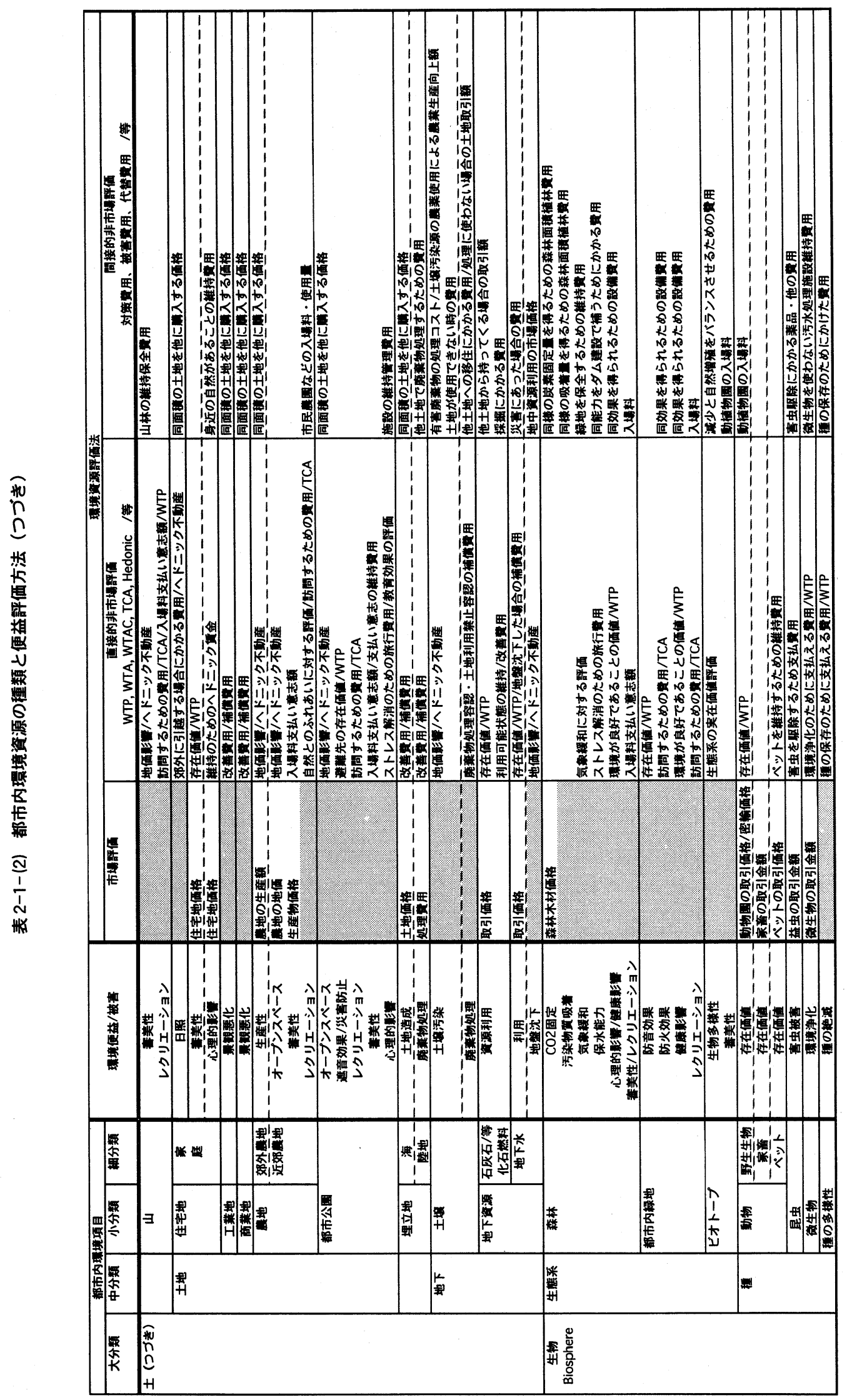


の研究で、都市内のエネルギーフローと、建設部門・廃棄 物部門のマテリアルフローを評価した。エネルギーフロー については、一次エネルギーが生産、転換（電力）、消費、 排出、リサイクルといった都市活動を通して、どのように 変化し、環境に負荷を及ぼすかといった一連の流れを評価 した2。マテリアルフローについては、建設部門・廃棄物部 門を取り上げ、関連した物質のフローとストックを評価し た3。本論文では、マテリアルフローに新たに民生部門を 組み込む。さらに水循環 ${ }^{4}$ 、環境負荷物質 ${ }^{5}$ を統合し、福岡 市の物質収支を作成する。

\section{2 推計結果}

図 3-1は、福岡市の物質収支をまとめたものである。移入量計 574万トン、移出量計 406 万トンであるので、福岡市内のストッ クは、蓄積傾向にある。特に、蓄積された建設資材は、建築物や 都市基盤の役割を終えた後、建設廃材となる。福岡市の蓄積量に 占めるリサイクルの割合は $18 \%$ である。循環型都市を目指すため には、このような廃棄物を資源としてリサイクルすることが必要 である。

\section{4. 兵的勘定のケーススタディ \\ 4. 1 間接的非市場評価}

\section{(1) 大気}

消費都市である福岡市においては、自動車からの排出ガスが大 気污染の主な原因である。ここでは、大気の間接的非市場評価と して、SOx とNOx、煤塺についての污染対策費用を推計する。

$\mathrm{SOx}$ ・煤塵については、福岡市の工場・事業場が設置している 脱硫装置・電気集塺機の設置・運転費用（表 4-1）より、対策費 用を求める。推計の結果を表 4-2に示す。年間処理費用は、 $\mathrm{SOx}$ が 3,100万円 / 年、煤塵が、6 億円 / 年となった。福岡市内では、 大規模工場・事業場が少ないために比較的小さな值となった。

NOx については、図 3-1 より排出総量 2,133 t に対して、 1,685t（79\%）が自動車であるので、三元触媒の価格により対策 費用を求める。メーカーへの取材によると触媒は普通乗用車のみ にしか取り付けていない。そこで、普通乗用車の耐久年数と年間 走行台キロにより年間対策金額を推計する。推計の結果を表 4-2 に示す。推計の際、三元触媒の価格を一台あたり 7 万円、普通自 動車の廃車までの総走行距離を 10 万 $\mathrm{km}^{6}$ とした。

以上より、大気污染対策費用による大気の間接的非市場評価額 は、約 55 億円である。

\section{（2）水}

博多湾は、湾口が狭く閉鎖性であることから、外海水の交換が 遅く陸地からの污濁物質が蓄積しやすい地形となっている。博多 湾の水質変化(COD)を図 4-1 に示す。1980 年代の COD は、70 年代に比べ下降傾向にあったが、90 年代に漸増傾向にある。図 4-2 が示すように、窒素に関する福岡市の污染排出源の約 7 割 は、下水処理水からの污染である。そこで、水資源の間接的非市

表 4-1 単位大気污染物得あたりの処理费用

\begin{tabular}{|c|c|c|c|}
\hline & 脱䃄装是 & 雪袋集度機 & 自動車三元触媒 \\
\hline 娍物需 & SOx & ばいじん & NOx \\
\hline 笔生源分類 & 固定源 & 固定源 & 移動源 \\
\hline 位処理コスト & 759 & 97 & 0.70 \\
\hline - & ( $\left(\mathrm{P}_{\mathrm{SO}} \mathrm{\textrm {N } m}\right.$ ) & $(\mathrm{P} / \mathrm{kg})$ & (用/台 $\mathrm{km}$ ) \\
\hline 位処理コストあたり削減 & 1 & 1 & 2.875 \\
\hline （単位） & $\left(\mathrm{SO}_{2} \mathrm{Nm}\right)$ & $(\mathrm{kg})$ & (g) \\
\hline
\end{tabular}

表 4-2 福岡における大気污染対策学用適用例

\begin{tabular}{|c|c|c|c|}
\hline & 脱硫䕐量 & 垔気集嘚機 & 自動車三元触媒 \\
\hline 対策曾（1992年 & 40,285 & & 6,860 \\
\hline （単位） & $\left(\mathrm{SO}_{2} \mathrm{Nm}^{\prime}\right)$ & - & (自方台自) \\
\hline & 58 & 6,600 & 19,724 \\
\hline （単位） & (tons) & (ton) & (ton) \\
\hline （単位） & $\begin{array}{r}31 \\
(\text { (百方成) }\end{array}$ & $\begin{array}{r}642 \\
\text { (百方方) }\end{array}$ & 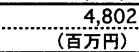 \\
\hline
\end{tabular}

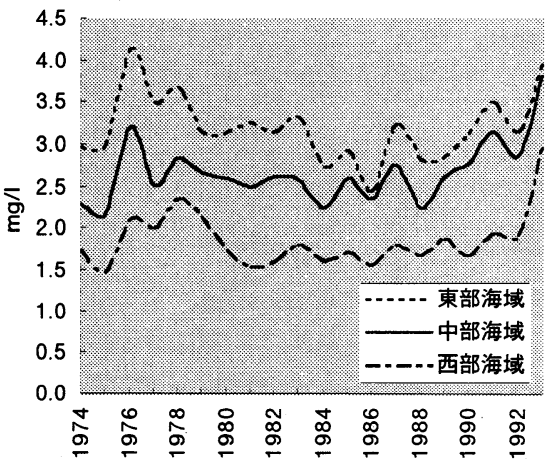

図 4-1 博多湾の水筫变化(COD)

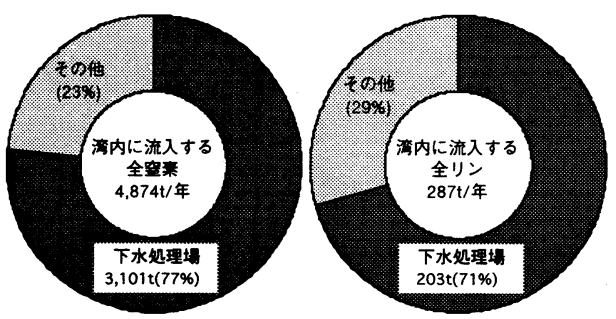

図 4-2 污染発生源（窒素・リン）

表 4-3 下水処理の処理能力と費用(1992 年)

\begin{tabular}{|c|c|c|c|}
\hline \multicolumn{2}{|l|}{ 処理場数 } & & 6 \\
\hline \multicolumn{2}{|l|}{ 処理能力 } & $\mathrm{m}^{2} /$ 日 & 611,000 \\
\hline \multirow[t]{5}{*}{ 年间処理量 } & SS & $t /$ 年 & 27,900 \\
\hline & COD & t/年 & 8,390 \\
\hline & BOD & t/年 & 22,100 \\
\hline & 全墨烹 & $t / 4$ & 2,600 \\
\hline & 全断 & $t / / 4$ & 642 \\
\hline \multirow[t]{2}{*}{ 処理震 } & 胥标曼 & 目万五/年 & 23,200 \\
\hline & 椺設 & 百方网/年 & 42,000 \\
\hline
\end{tabular}

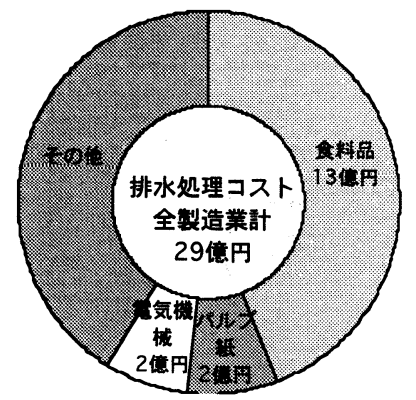

図 4-3製造業の排水処理貫用(1992 年) 
場評価として、都市内の水質污濁対策施設への投資額を推計す る。ここでは、公共下水処理施設と各産業の排水処理施設にか かる建設費と維持・管理費を推計する。

公共下水処理場の処理能力と運転費用は、表 4-3 のようにな る。処理能力については、下水処理場に流入する水質と放流す る水質の差に処理水量を乗じて求めた。 3 章で算定した福岡市 のCOD排出量は $1,100 \mathrm{t}$ であるので、総発生量は $9,500 \mathrm{t}$ となり、 除去率は $88 \%$ であることが分かる。

つぎに、都市内の製造業が、各污水処理設備に投資している 金額を推計する。具体的には、製造業種別の排水処理施設への 投資金額を全国值から比例配分により推計する。推計結果を図 4-3に示す。

以上より、水質污濁対策費用による水資源の間接的非市場評 価額は、約 671 億円となる。

\section{(3) 土}

都市内の緑地（都市公園）が地価に及ぼしている影響額の推 計を行う。推計にあたっては、都市ゾーン毎の地価関数を推定 し、いわゆるへドニックアプローチを行う。さらに、土地の市 場評価として都市内の地価総額を求め、影響額との比較を行う。

都市内において、1つのまちを形成している（中心部が明確 に分かっている商業地区・住宅地区を含む）地区を選定する。福 岡市内では、図 4-4のように、4つのゾーン（1都心・2 西新・ 3 香椎・ 4 大橋）に分類する。さらに、各ゾーン内の商業・業務 地区、住宅地区において、ヘドニックアプローチにより地価関 数を推定する。

地価関数の推定に関する既存研究 7 においては、関数型として 線形型、対数型、Box-Cox変換等が用いられているが、本研究 においては、住宅地および商業・業務地ともに対数型を採用し、

$$
\log V=a_{0}+\sum_{i=1}^{8} a_{i} x_{i}
$$

とする。回帰分析にはステップワイズ法を用い、推定に用いた 変数の定義は、表 4-4の通りである。被説明変数は1995年の公 示地価と福岡県基準地価格を用い、説明変数は公示地価と福岡 県基準地価格の記載事項および、取材データを用いる。

上記にて求めた地価関数をさらに都市内緑地施設に適用して、 この市場価值評価を行う。具体的な都市内緑地施設として大濠

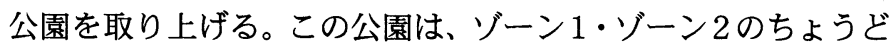
中間に位置する。そこで、公園が存在しない場合の地価分布を 推計し、実際値と推計值との差から公園の存在価値を算定する。

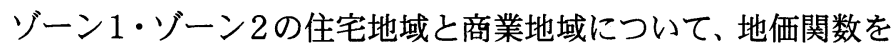
推計した結果は、表 4-5 の通りである。この関数から推計され た公園周辺地区の地価と実際の地価を比較し、都市公園による 影響を算出する。公園からの距離 $\mathrm{X}$ と、影響值 $\mathrm{Y}$ の関係式は、

$$
\ln \mathrm{Y}=-0.009 \mathrm{X}+12.691
$$

$\mathrm{t}$ 值 (-4.684) (62.159)

となる（図 4-5）。式 2 を積分して求めた公園の周辺地への影響

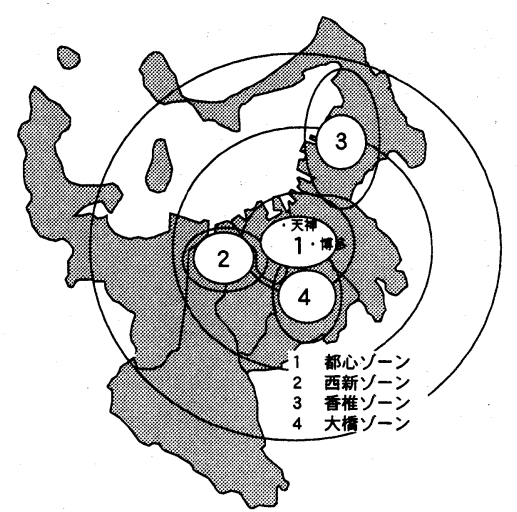

図 4-4 都心ソーンの分類

\begin{tabular}{|c|c|c|}
\hline 钎号 & 変数 & 単位 \\
\hline $\mathrm{V}$ & 公示地侕 & 円 $/ \mathrm{m}^{2}$ \\
\hline a1 & 都心部から最害駅までの時间距教 & 分 \\
\hline a2 & ゾーン中心部から最寄歐までの時間距噰 & 分 \\
\hline a3 & 最害り臤までの距䧼 & $\mathrm{km}$ \\
\hline a4 & 地積 & $\mathrm{m}^{2}$ \\
\hline a5 & 接面道路幅 & $\mathrm{m}$ \\
\hline a6 & 下水道タミー & - \\
\hline a7 & 第一程住居軎用地域タミー & - \\
\hline a8 & 第二程住居軍用地域タミー & - \\
\hline
\end{tabular}

表 4-4 地価関数に使用した変数

表 4-5 地価関数推計結果
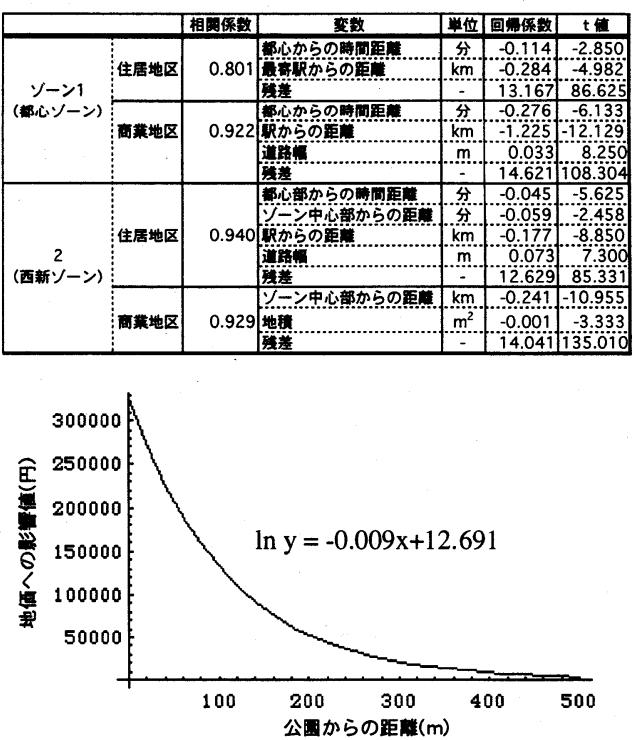

図 4-5＼cjkstart都市公園の地価への影暗

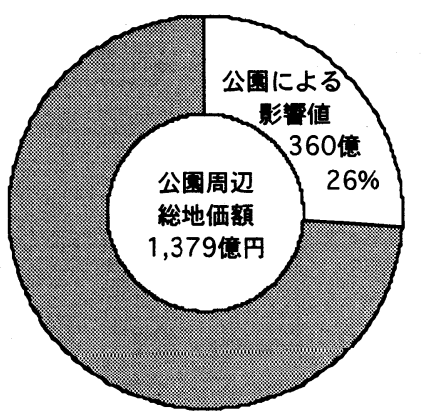

図 4-6 都市公園の地価への影響額 
額は、有効影響距離 $400 \mathrm{~m}$ として推定すると、約 360 億円となった。これに対して、公園周辺（400 m圈内） の地価総額は、実際值を元に推測すると約 1,379 億円となる。図 4-6 のように、前記の影響額の地価に閉め る割合は、26\%となる。

\section{2 直接的非市場評価}

大気・水に関する直接的非市場評価のために、福岡 市民を対象に住民意識調査を実施した。調査期間は平 成 8 年 8 月 8 日〜 16 日で、福岡市内の 150 地点におい て 324 通を配布した。回収は郵送法により行い、回収 数は 95 通、回収率は $29 \%$ であった 8 。「空気のきれい さ」、「静けさ」、「周辺の水辺」、「周辺のみどり」につ いて次の 3 種類の方法で価値を尋ねた。a 家計支出と の相対比較による環境の価値、 $\mathrm{b}$ 環境改善のための支 払い意志額、 $\mathrm{c}$ 容認のための補償費用受取額。aにつ

表 4-6 直接的非市場評価の適用例

\begin{tabular}{|c|c|c|c|c|}
\hline & & $\begin{array}{c}\text { a. 家計支出との } \\
\text { 相対評俩 }\end{array}$ & $\begin{array}{c}\text { b.改蕃のための } \\
\text { WTP }\end{array}$ & $\begin{array}{c}\text { c.現状に対する } \\
\text { WTAC }\end{array}$ \\
\hline 筫問項目 & & 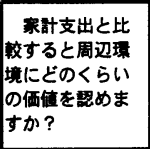 & $\begin{array}{l}\text { 周辺懪暁を望 } \\
\text { ましいレへルま } \\
\text { で改萻するため } \\
\text { にいくらまで支 } \\
\text { 払っても良いで } \\
\text { すか? }\end{array}$ & 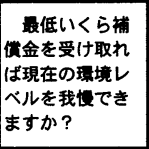 \\
\hline 有効回答数 & & 64 & 20 & 20 \\
\hline $\begin{array}{l}\text { 回答金案平均 } \\
\text { (円/月-世带) }\end{array}$ & 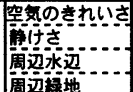 & . & . 1,500 & $\begin{array}{l}3,500 \\
5,400 \\
2,200 \\
3,700\end{array}$ \\
\hline $\begin{array}{c}\text { 対䄚岡市全人口 } \\
\text { (百万円) }\end{array}$ & 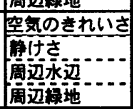 & $\begin{array}{r}1,000 \\
17,400 \\
\ldots .17,900 \\
\ldots .11,200 \\
15,400\end{array}$ & $\begin{array}{r}3,4000 \\
\ldots .3,600 \\
\ldots . .3,400 \\
2,800\end{array}$ & $\begin{array}{r}7,200 \\
10,600 \\
-7,000 \\
7,500\end{array}$ \\
\hline
\end{tabular}
いては、家計支出を尋ねた上で、各環境項目に対して価格付けするものとした。 $b$-cについては、周辺環境 が望ましいレベルに達していないと回答したに人に尋ねた。表 4-6は、これらの集計結果を示したものであ る。都市全体での評価を行う際に以下を考慮して行った。aに関しては、回答金額をそのまま都市全世帯数に 比例配分した。 $b$ ・c に関しては、全世帯数に環境が望ましいレベルに達していないと答えた人の割合を乗じ 有効世帯数とし、さらに、回答金額に有効世帯数を乗じて都市全体の評価とした。都市全体での評価結果は、 有効世帯数の関係上 $\mathrm{a}$ が最も大きくなった。環境項目別にみると、三つの評価を通して「静けさ」が最も大き く、 a 179 億円、b 36 億円、 c 106 億円となった。また、評価手法別にみると、一般的に議論されているよ うに、WTPによる值がWTACによる值より全体的に小さくなり、二評価の乘離が目立つ結果となった。

\section{5. まとめ}

表 5-1 非市場伻価の適用結果

表5-1は、今回算定した質的評価の結果を まとめたものである。評価価値が最も大き かったのは水質污染対策費用で700億円、最 も小さかったのは周辺緑地の改善WTPで 28 億円であった。本論文では、地域の環境資源 勘定に必要な基礎データおよび、環境価値の 評価例を示した。貨幣換算による環境資源の 経済評価は、人々が容易に認識できる客観的

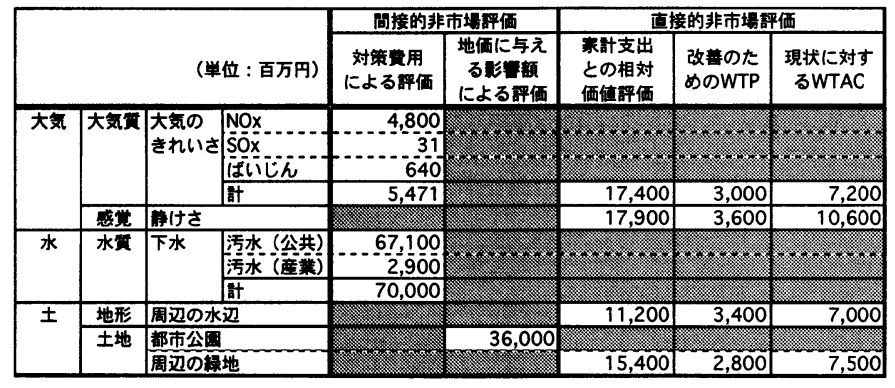
手法として非常に有 効であるが、市場性のない環境資源を貨幣換算すること自体感覚的に認識し難い面があ る。今回算定した大気や水・土地の価値もその結果を評価するに至っていない。質的勘定の評価体系や手法に ついては、今後議論を深めていく必要がある。

\section{【参考文献】}

1) United Nations, Handbook of National Accounting : Integrated Environmental and Economic Accounting, New York, pp24, 1992

2）谷川寛樹・井村秀文、地域に着目した環境資源勘定の構築、環境システム研究、Vol.22、pp400-407、1994

3）谷川寛樹・藤倉良・井村秀文、都市の物質収支と環境資源勘定に関する研究 : 建設用資材の投入と建設副産物、環境システム 研究、Vol.23、pp274-278、1995

4）大平晃司・井村秀文ら、地域の水資源に着目した環境資源勘定の構築に関する研究、環境システム研究、Vol.23、pp321325、 1995

5）（財）福岡都市科学研究所、都市活動と環境に関するシステムの研究、1995

6）（社）資源協会編、家庭生活のライフサイクルエネルギー、あんほるめ、pp101、1993

7）肥田野登、ヘドニックアプローチによる社会資本整備便益の計測とその展開、土木学会論文集、No449/N-17、pp37-46、 1992

8）貞森一範・谷川寛樹・松本亨・井村秀文、都市の環境資源勘定と環境課値の評価に関する研究 : 周辺環境及び都市公園、博多 湾のケーススタディ、環境システム研究、Vol.24、1996 